\title{
Methodology of assessment of the level of social responsibility of oil and gas enterprises in Ukraine
}

\author{
Romana Matskiv* \\ Department of Theory of Economics \\ and Management \\ Ivano-Frankivsk National Technical \\ University of Oil and Gas \\ Ivano-Frankivsk, Ukraine \\ chrt50_32@ukr.net
}

\author{
Tetiana Topolnytska \\ Department of Theory of Economics \\ and Management \\ Ivano-Frankivsk National Technical \\ University of Oil and Gas \\ Ivano-Frankivsk, Ukraine \\ rtcb@ukr.net \\ Irina Savchyn \\ Department of Theory of Economics \\ and Management \\ Ivano-Frankivsk National Technical \\ University of Oil and Gas \\ Ivano-Frankivsk, Ukraine \\ savshin.i@gmail.com
}

\author{
Olha Romanko \\ Department of Theory of Economics \\ and Management \\ Ivano-Frankivsk National Technical \\ University of Oil and Gas \\ Ivano-Frankivsk, Ukraine \\ olgaromanko11@gmail.com
}

\begin{abstract}
The article focuses on the need to develop a common methodology for assessing the level of social responsibility of enterprises. The purpose of this study is to determine the level of social responsibility of oil and gas enterprises, which is based on the calculation of partial and integral indicators, taking into account the importance of certain features of socially responsible activity of the economic entity. The assessment of the level of social responsibility of oil and gas enterprises is based on the analysis of quantitative and qualitative indices of social investments. The methodology for calculating partial and integral quality indices of social investment has been improved by introducing weighting coefficients that are determined by experts and establish the importance of the main areas of socially responsible activity.
\end{abstract}

Keywords - social responsibility, quantitative and qualitative indices, oil and gas enterprises, Ukraine.

\section{INTRODUCTION}

Constant growth of economy and society stipulates the necessity to determine the optimal level of interaction between enterprises and parties, interested in their activities. The realization of the corporate concept of corporate social responsibility (CSR) can be considered to be one of possible ways of such interaction. It was developed and introduced into the practice of corporate governance in the USA in 1950-1960 [1]. In Ukraine, scholars started studying socially responsible aspects of companies activities after the 2000s. And only after 2010 there were publications that systematically characterized aspects of social responsibility of Ukrainian companies [2], [3].

Alexander Dahlsrud [4] has found that stakeholder theory is one of the approaches to CSR interpretation. The scientific community and the public emphasize the importance of implementing the principles of social responsibility, which is one of the prerequisites for the effective functioning of both business entities and the social sphere.

\section{THEORETICAL BACKGROUND}

Social responsibility performance is assessed using a variety of indicators, indices and models. In her papers, Miriam Jankalová [5] indicates that socially responsible activities of companies are assessed by independent agencies using the following indices: Dow Jones from Switzerland, Ethiopia from Belgium, FTSE from the UK Belgium, EIRIS from UK, OEKOM Research AG from Germany. Companies are rated $\mathrm{n}$ accordance with the results of such indicators, which, accordingly, demonstrate their social responsibility. These non-fund indices are based on an assessment of the company's responsibility to different stakeholder groups. Jankalová Miriam and Jankal Radoslav also explore in detail different approaches and models that make it possible to evaluate the CSR of companies [6].

Representatives of the scientific community in Ukraine pay considerable attention to the problems of implementing CSR principles, as well as assessing the level of social responsibility of companies [7]. However, in Ukraine a unified approach to solving this problem has not yet emerged and scientists propose different approaches to assessing the level of corporate social responsibility.

At the same time, one should pay attention to Sheehy [8]. This scholar argues that the implementation of a CSR policy by the organization must include all its aspects, that is, compliance with environmental regulations, ensuring environmental constituent, ensuring human rights, creating appropriate employment conditions, ethical business practices in relations with partners, suppliers and consumers and social impact starting from basic compliance with established legislation. And then gradually move towards consideration of stakeholder issues.

On the basis of the above mentioned, we consider it advisable to propose a methodology for assessing the level of social responsibility of oil and gas enterprises, which function as separate structural units of transregional economic entities to their stakeholders. 


\section{METHODOLOGY}

Choosing a single methodology for assessing the level of social responsibility (SR) of oil and gas enterprises is an important and at the same time difficult task. This is due to the fact that the oil and gas companies comprise enterprises engaged in various activities. In such circumstances, it is important for transregional economic entities to formulate general areas of social responsibility, appropriate measures and approaches to assess its results.

In our view, it is appropriate to use quantitative and qualitative indices to assess the level of social responsibility of oil and gas enterprises. On the basis of this we propose to calculate the quantitative indices of the level of social responsibility of oil and gas enterprises.

One of the five aspects of social responsibility is the stakeholder theory [4], which directly or indirectly affects enterprise activities. We suggest to divide them into representatives of the internal and external sphere of enterprise activities. Accordingly, for a quantitative analysis of the level of social responsibility to the local community, we consider it appropriate to calculate social investment indices separately for the internal and external spheres. Therefore, it is proposed to separately allocate the total amount of social payments to the amount of investment in the objects of the internal sphere and, accordingly, the external one.

Employees are considered to be representatives of the internal sphere of social responsibility of enterprises, structural subdivisions of transregional economic unities, can be considered mainly, since they are mostly members of local communities (as opposed to shareholders). Then, the above indicators of quantitative assessment of social responsibility in the internal sphere should be calculated as follows:

- index of social investment in the internal sphere per employee $I L i$ (in monetary units):

$$
I L i=\frac{C i}{L}
$$

where $\mathrm{Ci}$ - the amount of mandatory and voluntary social payments to employees of the enterprise under various social programs;

$L$ - average number of personnel of the enterprise;

- share of social investment in total sales revenue (total sales) (in \%):

$$
I S i=\frac{C i}{S} \cdot 100 \%,
$$

where $S$ - cumulative sales revenue (gross sales);

- $\quad$ share of social investments in the internal sphere in the amount of profit before tax (in \%):

$$
I P i=\frac{C i}{P} \cdot 100 \%,
$$

Similarly, it is proposed to calculate such indicators to determine the level of social responsibility to the stakeholders of the external sphere. At the same time, social payments will be provided by charitable assistance to the community, investment in social projects, social assistance to former employees, pensioners, their families and more.

A qualitative social investment index, as opposed to a quantitative one, is designed to assess the complexity and completeness of a phenomenon such as social responsibility. The basis for the calculation of this index is the presence (full or partial) or absence of facts of socially responsible behavior in the responding business structure. Accordingly, there are partial and general qualitative indices of social investment. It is necessary to consider the qualitative component of the social investment process due to the fact that the amount of resources allocated to social programs is only one of the characteristics of the socially responsible activity of the entity.

The complexity of social investment is assessed on the basis of the following five items of expenditure: company staff development, creation of proper working conditions, environmental policy and resource conservation, support of honest business practices, development of local communities.

We think that these items of expenditure form the maximum diversity of an economic entity social policy, since the concentration of social investments in one or two directions leads to disproportions in the development of the entire social and economic system.

Information on the presence or absence of each of the proposed characteristics is summarized by a single integral indicator, the qualitative index of the level of social responsibility (IK), the method of calculation of which is developed on the basis of the approach proposed by the Association of Managers of Russia. At the same time, it issuggested to introduce a weighing factor into the calculation formula, the value of which is determined on the basis of expert estimates. Thus, the integral indicator, that is the general qualitative index of level of social responsibility $(I K)$, characterizing complexity of socially responsible activity of the enterprise (organization), is calculated as follows:

$$
I K=\sum_{i=1}^{n} \beta_{i} \cdot I K p(i)
$$

where $\beta_{i}$ is a weighing coefficient, which indicates the importance of the presence of the $i$-th group of features in the activity of the enterprise (organization);

$n$ is the number of groups into which the attributes are grouped;

$I K p(i)$ is a partial qualitative index of the level of social responsibility for the $i$-th group of indicators characterizing the social responsibility of the enterprise:

$$
I K p(i)=\sum_{j=1}^{m} \lambda_{i j} \cdot X_{j},
$$

where $P$ is the total amount of profit before tax. 
where $\lambda i j$ is a weighting factor that indicates the importance of having the $j$-th characteristic of the $i$-th group in the socially responsible activities of the enterprise;

$X j$ is a variable that acquires a value of 1 if the $j$ - th sign is present in the $i$-th group and it equals 0 , if that sign is absent, and acquires a value of 0.5 , provided that it is partially present;

$m$ is the number of features in the $\mathrm{i}$-th group.

Both partial and integral qualitative index of social investments can take values from 0 to 1 . The approximation of the values of each index to their maximum, which is interpreted as 1 , characterizes the integrity and success of the social policy of an enterprise. At the same time comparing the values of the partial indexes of $I K(i)$ for different groups of features makes it possible to identify the corresponding "bottlenecks", for instance those that represent the biggest problem for an enterprise. The purpose of $I K$ integral social responsibility index is twofold.

First of all, weighting coefficients, calculated on the basis of the results of the survey of employees and experts indicate not only the importance of a particular group of indicators for the social activity of an company, but also the level of familiarization of the employees of the enterprise with the principles of social responsibility.

Secondly, comparing indices for different enterprises allows us to identify leaders and outsiders in terms of the complexity of organizing the process of socially responsible activities.

To obtain the information needed to assess the qualitative characteristics of socially responsible enterprises, the questionnaire method was chosen. It is the survey of employees and experts of economic entities that will allow to determine the presence (full or partial) or absence of characteristics that characterize spheres, selected for social responsibility assessment.

The next stage is the systematization of statistical and accounting data and the results of questionnaires of employees and experts.

On the basis of systematic material, quantitative and qualitative indices of the level of social responsibility are calculated, as well as the overall dynamics of indicators of the level of responsibility to the employees of the enterprise is estimated.

The next two steps involve the analysis of the calculated indicators, their interpretation, identification and concretization of problems in the studied areas. At the final stage, the recommendations, aimed at solving the identified problems are being developed and laid down.

It is important to note that at any stage of the analysis of the level of social responsibility of the business structure, it may be necessary to return to the previous or even the initial stage for various reasons: unreliability or limited amount of information, incorrectly selected methods of analysis, no common needs identified and no appropriate management goals make it impossible to form an adequate management mechanism, etc.

\section{RESUlTS}

Therefore, in order for social responsibility to become one of the important strategic directions of development of subjects of economic activity of the oil and gas complex in Ukraine, it is necessary to be able to objectively and correctly analyze its status at the enterprise at a certain point in time, and there should be a possibility to compare similar indicators for different enterprises in the same industry or those that are part of the same company. Adequately and properly conducted assessment of the CR status, in accordance with the steps that characterize the logical and structural sequence, gives an opportunity to identify both the developed areas of social policy and its shortcomings and bottlenecks. This, in turn, will effectively manage the segregated structural units of trans-regional business entities and achieve both the tactical and strategic goals of company operations.

On the basis of the abovementioned, we consider it appropriate to assess the social responsibility of the basic level (economic and legal responsibility in the A. Carroll's model [9]). Accordingly, assessing the SR in this aspect, it should be emphasized that oil and gas enterprises operating in a certain territory provide its population with jobs, respectively, create the opportunity to receive wages, social security, and their contribution to local budgets is extremely important. That can be proved by the data calculated on the basis of the available information and shown in Table 1.

Summarizing the data presented in the table, it can be argued that oil and gas enterprises play a significant role in generating local budget revenues. In particular, it is worth noting that in the Dolyna district, the oil and gas production department provides more than $30 \%$ to fill the local budget. At the same time, the amount of land payment paid by Oil and Gas Production Unit "Dolynanaftogaz" is about $90 \%$ of the total amount of payment that comes to the local budget.

It is also possible to say that oil and gas production unit "Nadvirnanaftogaz" plays the similar role in forming the budget of the appropriate level. To summarize the information, it is worth stating that oil and gas enterprises are budget-forming for the territories where they operate. The table does not reflect changes in Ukrainian tax legislation that came into force on January 1, 2018. According to these changes, the rent for the use of mineral resources for the extraction of minerals in the amount of 5\% remains in the local budgets. In absolute terms, these are significant volumes. Namely, as of July 1, 2018 UAH the regional budget received 18 million $\mathrm{UAH}$, that is about $5 \%$ of its total amount. As for the districts of the region, such as Dolyna, Nadvirna and Rogatyn Districs where production facilities are concentrated, $6 \%$ of their total budgets are formed by rent payments. During this period, the budget of Nadvirna district received 5 million 605 thousand UAH of rent payments. The funds that were to be split, according to the legislation, were allocated to the district budget in the amount of 3 million 732 thousand UAH. This situation demonstrates the appropriate level of economic and legal responsibility of the oil and gas enterprises, which should be an additional incentive for the realization of social responsibility, which creates potential conditions for profit from other activities. 
TABLE I. LOCAL BUDGETS CONTRIBUTION OF OIL AND GAS ENTERPRISES OF IVANO-FRANKIVSK REGION

\begin{tabular}{|c|c|c|c|c|c|c|}
\hline Year & \multicolumn{2}{|c|}{2016} & \multicolumn{2}{|c|}{2017} & \multicolumn{2}{|c|}{2018} \\
\hline Enterprise & 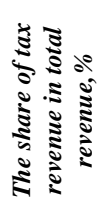 & 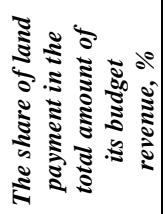 & 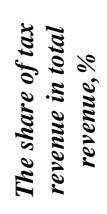 & 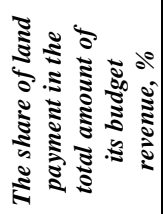 & 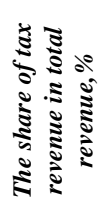 & 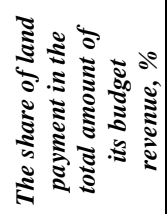 \\
\hline Oil and Gas Production Unit "Dolynanaftogaz" & $32.46^{\mathrm{a}}$ & 90.54 & 34.76 & 86.73 & 19.33 & 57.83 \\
\hline Oil and Gas Production Unit "Nadvirnanaftogaz" & 18.52 & 34.38 & 19.88 & 38.85 & 17.96 & 29.33 \\
\hline Department of Main Gas Pipelines "Prykarpattransgaz" & 1.80 & 1.05 & 4.94 & 1.06 & 4.95 & 1.06 \\
\hline Research and Project Institute of PJSC "Ukrnafta" & 0.88 & 0.10 & 1.03 & 0.17 & 1.07 & 1.01 \\
\hline
\end{tabular}

a. Source: it is calculated according to the data of Ivano-Frankivsk State Tax Administration and the Main Department of Economics of Ivano-Frankivsk Regional State Administration.

The next stage of the study is calculation and interpretation of quantitative and qualitative indices of the level of social responsibility of oil and gas enterprises in the internal and external sphere. We consider it expedient to point out that social payments to employees, assistance to members of local communities and financing of other activities can be considered as manifestation of socially responsible behavior of business structures. At this stage, enterprises that invest in social sphere are contributing to improving the quality of life of people through creation of new technologies and mechanisms for the distribution of resources between different population groups, taking into account their needs. Social investments are aimed at strengthening the social orientation of the economic system: achieving environmental security, stimulating economic growth, appropriate distribution and redistribution of benefits, providing a guaranteed level of education and medical care, nutrition, providing transfers to those whose incomes do not reach the level of the established minimum guaranteed income. Therefore, it can be noted that a key characteristic of social investment within the framework of corporate social responsibility is to obtain a certain beneficial effect on society.

According to the approach outlined above, social payments made by oil and gas enterprises can be considered as a manifestation of socially responsible behavior. Therefore, in order to assess the level of social responsibility of oil and gas enterprises, it is advisable to use the proposed methodology for calculating quantitative and qualitative indices. These indicators are calculated separately to assess the level of social responsibility to the employees of the enterprise and the local community.

As it can be seen from the results of the calculations made on the basis of data received at the enterprise and presented in Table 2, there is a slight lag of quantitative indicators of SR level in the local community from similar indicators in the area of responsibility towards employees. At the same time, it is worth noting that the share of social payments to both internal and external stakeholders is extremely low - from $0.2 \%$ to $4.4 \%$ of the value of commodity product.

TABLE II. QUANTITATIVE INDICATORS OF SOCIAL RESPONSIBILITY

\begin{tabular}{|c|c|c|c|c|c|c|c|c|c|c|c|c|}
\hline \multirow[t]{2}{*}{ Indicator } & \multicolumn{3}{|c|}{$\begin{array}{c}\text { Oil and Gas } \\
\text { Production Unit } \\
\text { "Dolynanaftogaz" }\end{array}$} & \multicolumn{3}{|c|}{$\begin{array}{c}\text { Oil and Gas } \\
\text { Production Unit } \\
\text { "Nadvirnanaftogaz" }\end{array}$} & \multicolumn{3}{|c|}{$\begin{array}{c}\text { Research and Design } \\
\text { Institute of PJSC } \\
\text { "Ukrnafta" }\end{array}$} & \multicolumn{3}{|c|}{$\begin{array}{l}\text { Department of Main } \\
\text { Gas Pipelines } \\
\text { "Prykarpattransgaz" }\end{array}$} \\
\hline & 2016 & 2017 & 2018 & 2016 & 2017 & 2018 & 2016 & 2017 & 2018 & 2016 & 2017 & 2018 \\
\hline \multicolumn{13}{|c|}{ - towards employees } \\
\hline $\begin{array}{l}\text { The share of employees who have had } \\
\text { advanced training and acquired new } \\
\text { professions, } \%\end{array}$ & $31.4^{\mathrm{b}}$ & 33.7 & 31.4 & 32.0 & 28.4 & 17.8 & 5.7 & 3.5 & 5.6 & 14.1 & 14.5 & 14.7 \\
\hline $\begin{array}{l}\text { Social payments to employees per } 1 \\
\text { employee, UAH/1 person }\end{array}$ & 2275 & 2588 & 2370 & 2671 & 2792 & 2569 & 1199 & 1263 & 1281 & 1411 & 1540 & 1597 \\
\hline $\begin{array}{l}\text { The share of social payments to employees } \\
\text { in the value of commodity products, } \%\end{array}$ & 0.62 & 0.61 & 0.74 & 1.08 & 1.35 & 1.62 & 0.7 & 0.8 & 0.5 & 1.69 & 3.20 & 4.40 \\
\hline \multicolumn{13}{|c|}{ - towards local community } \\
\hline $\begin{array}{l}\text { Social payments to members of the local } \\
\text { community (former employees, their } \\
\text { families) for } 1 \text { employee, UAH/1 person }\end{array}$ & 2101 & 2001 & 1982 & 2183 & 2130 & 1922 & 1302 & 1314 & 1488 & 779 & 867 & 854 \\
\hline $\begin{array}{l}\text { incl. charitable assistance to the community } \\
\text { for } 1 \text { employee }\end{array}$ & 389 & 309 & 241 & 503 & 623 & 238 & 0 & 0 & 0 & 0 & 0 & 0 \\
\hline $\begin{array}{l}\text { The share of social payments to } \\
\text { representatives of the local community in } \\
\text { the value of commodity products, } \%\end{array}$ & 0.54 & 0.39 & 0.44 & 0.93 & 0.85 & 0.95 & 0.2 & 0.3 & 0.15 & 0.33 & 0.4 & 0.4 \\
\hline $\begin{array}{l}\text { Share of payments for environmental } \\
\text { protection in the value of commodity } \\
\text { products, } \%\end{array}$ & 0.26 & 0.18 & 0.21 & 0.62 & 0.42 & 0.36 & - & - & - & - & - & - \\
\hline
\end{tabular}

b. Source: it is calculated by the authors on the basis of accounting, financial reporting and other reporting of enterprises

The available calculations make it possible to ascertain a slightly higher level of social responsibility in both the internal and external spheres of Oil and Gas Production
Units than the Research and Project Institute and the Department of Main Gas Pipelines. 
In particular, the share of employees who have had advanced training at Oil and Gas Production Unit "Dolynaftogaz" and Oil and Gas Production Unit "Nadvirnaftogaz" ranges from $33.7 \%$ to $17.8 \%$. At the same time, the similar indicator in the Department of Main Gas Pipelines "Prykarpattransgaz" is only slightly more than 14\%. Due to pecularities of the Research and Project Institute's activities, its employees do not require further training, as they are constantly engaged in self-education in connection with the production need. At the same time, the calculated indicators testify to different policies in the sphere of social responsibility of the main companies, which include the mentioned enterprises.

As for social payments to employees in the calculation of the amount per employee, the worst situation was in the Research and Design Institute of PJSC "Ukrnafta". This can be explained by the general social policy of the company, aimed at supporting production staff, although it must be noted that the average salary at the Research and Design Institute is a bit higher than at any of the Oil and Gas Production Units.

As for social responsibility to local community representatives, it is not always the best one with a tendency to deteriorate: the amount of social payments (including charitable assistance) is constantly decreasing. This situation is caused by the generally difficult economic situation. Therefore, we need a scientifically and methodologically sound management of social responsibility to improve the situation.

Along with the quantitative assessment of the level of social responsibility, it is advisable to evaluate its qualitative level on the basis of the results of calculations of partial and integral qualitative indices of social responsibility. According to the proposed methodology, the calculation is made on the basis of the results of questionnaires of employees and experts of the enterprises where the research was conducted.

The values of the weighting coefficients of the relevant features characterizing social responsibility were determined by the method of paired comparisons. The calculation of the values of the partial coefficients is based on the determined weighting coefficients and the results of the questionnaire. The calculated partial qualitative indices of the level of social responsibility are presented in Table 3 .

TABLE III. PARTIAL QUALITATIVE INDICES OF SOCIAL INVESTMENTS

\begin{tabular}{|c|c|c|c|c|}
\hline \multirow[b]{2}{*}{ Sphere of responsibility } & \multicolumn{4}{|c|}{ Enterprise } \\
\hline & $\begin{array}{c}\text { Oil and Gas } \\
\text { Production Unit } \\
\text { "Dolynanaftogaz" }\end{array}$ & $\begin{array}{c}\text { Oil and Gas } \\
\text { Production Unit } \\
\text { "Nadvirnanaftogaz" }\end{array}$ & $\begin{array}{l}\text { Department of Main } \\
\text { Gas Pipelines } \\
\text { "Prykarpattransgaz" }\end{array}$ & $\begin{array}{c}\text { Research and } \\
\text { Project Institute of } \\
\text { PJSC "Ukrnafta" }\end{array}$ \\
\hline $\begin{array}{l}\text { Staff development, creation of decent working } \\
\text { conditions and their institutional support }\end{array}$ & $0.878^{\mathrm{c}}$ & 0.709 & 0.698 & 0.674 \\
\hline Environmental policy and resource conservation & 0.379 & 0.540 & 0.395 & 0.194 \\
\hline Economic activity & 0.624 & 0.546 & 0.457 & 0.500 \\
\hline Local communities & 0.511 & 0.590 & 0.296 & 0.296 \\
\hline
\end{tabular}

c. Source: it is calculated by the authors according to the formula 5 on the basis of data obtained by questionnaire of the personnel of enterprises

The values of partial qualitative indices of social investments demonstrate problem areas of SR implementation from the point of view of enterprise representatives themselves. In particular, the situation in the area of environmental policy and resource conservation as well as responsibility to the local community is the worst as evidenced by the fact that the lowest values are actually the lowest values of partial qualitative indices.
While calculating the overall qualitative indicator of the level of social responsibility, it is necessary to define the value of the weighting coefficients for each area of social responsibility in the enterprises being surveyed. This definition is also made by the method of pairwise comparisons. Therefore, the overall qualitative indicator of the level of social responsibility of the enterprise (organization) will be carried out according to the following formulas:

- for Oil and Gas Production Unit "Dolynanaftogaz" $\left(I K_{D}\right)$ :

$$
I K_{D}=0.198 \cdot I K_{1}+0.347 \cdot I K_{2}+0.347 \cdot I K_{3}+0.107 \cdot I K_{4}
$$

- for Oil and Gas Production Unit "Nadvirnanaftogaz" $\left(I K_{N}\right)$ :

$$
I K_{N}=0.221 \cdot I K_{1}+0.366 \cdot I K_{2}+0.321 \cdot I K_{3}+0.092 \cdot I K_{4}
$$

- $\quad$ for the Department of Main Gas Pipelines "Prykarpattransgaz" $\left(I K_{P}\right)$ :

$$
I K_{P}=0.291 \cdot I K_{1}+0.156 \cdot I K_{2}+0.415 \cdot I K_{3}+0.087 \cdot I K_{4}
$$

- $\quad$ for the Research and Project Institute of PJSC “Ukrnafta” $\left(I K_{R P I}\right)$ : 


$$
I K_{R P I}=0.374 \cdot I K_{1}+0.107 \cdot I K_{2}+0.415 \cdot I K_{3}+0.104 \cdot I K_{4}
$$

where $I K_{l}-$ partial qualitative index by group, characterizing the social responsibility of the enterprise in the sphere of personnel development, creation of decent working conditions and institutional registration of relations with employees;

$I K_{2} \quad$ - partial qualitative index for the group characterizing the social responsibility of the enterprise in the field of environmental policy and resource conservation;

$I K_{3}$ - partial qualitative index for the group characterizing the social responsibility of the enterprise in the sphere of economic activity;

$I K_{4} \quad$ - partial qualitative index for the group characterizing the social responsibility of the enterprise in the local community.

The results of the calculation of the general qualitative index of the level of social responsibility of economic structures are presented in Table 4 . The determination of the level of social responsibility is carried out using the Harrington scale of qualitative assessments, according to which the level of social responsibility of the enterprise is unsatisfactory if the quality index takes values from 0 to 0.2 ; low - from 0.21 to 0.37 ; the average is from 0.38 to 0.64 ; satisfactory is from 0.65 to 0.8 ; and high is from 0.81 to 1 .

TABLE IV. THE LEVEL OF SOCIAL RESPONSIBILITY

\begin{tabular}{|l|c|}
\hline \multicolumn{1}{|c|}{ Enterprise (organization) } & $\begin{array}{c}\text { An integrated qualitative index of } \\
\text { the level of social responsibility }\end{array}$ \\
\hline $\begin{array}{l}\text { Oil and Gas Production Unit } \\
\text { "Dolynanaftogaz" }\end{array}$ & $0.577^{\mathrm{d}}$ \\
\hline $\begin{array}{l}\text { Oil and Gas Production Unit } \\
\text { "Nadvirnanaftogaz" }\end{array}$ & 0.584 \\
\hline $\begin{array}{l}\text { Department of Main Gas } \\
\text { Pipelines "Prykarpattransgaz" }\end{array}$ & 0.480 \\
\hline $\begin{array}{l}\text { Research and Project Institute } \\
\text { of PJSC "Ukrnafta" }\end{array}$ & 0.511 \\
\hline
\end{tabular}

d. Source: it is calculated by the authors by formulas 6-9 based on the values of the partial coefficients, which are presented in Table 3

On the basis of the abovementioned facts, it is undeniable that the structural divisions of PJSC "Ukrnafta" and other companies are implementing social responsibility policy on average level, but the assessment of its effectiveness may be the subject of future research.

\section{CONCLUSIONS}

From our point of view, the realization of the concept of corporate social responsibility by entities and companies that are part of "Naftogaz of Ukraine" has several shortcomings: non-systematic, fragmentary, sometimes declarative charcter of the policy; the selection of SR components for implementation is somewhat centralized (in regional centers), and not directly with the community management bodies within the territorial units of the transregional economic entities; implementation of the SR concept only at the location of the head office (or center) of the company without taking into account the needs of local communities and the consequences of activities in other territories where their enterprises are functioning; SR actions are primarily aimed at addressing current problems (e.g. infrastructure related repair, etc.); financial transactions do not directly support the implementation of strategic programs for social and economic development of communities; there are practically no SR measures aimed at eliminating and preventing negative impact on the environment; SR measures do not contribute to the achievement of strategic goals of both the enterprise and the company; low level of public awareness of the measures taken, which does not meet a number of basic principles of socially responsible activities.

In order to eliminate these shortcomings, oil and gas companies need to pay attention to the experience of world companies. In particular, oil companies in Mexico represent CSR as a tool for regional development, and in their business plans for 2010-2025 they set out four-way tasks. CSR policy is integrated into the activities and programs of companies for the sustainable development of society and for improving the quality of life of citizens [10].

It is also important to develop mechanisms for implementing the concept of social responsibility of oil and gas companies that would provide them with the opportunity to benefit from such activities. The main condition for the formation of such a mechanism is the implementation of SR enterprise through social investment within the strategic development of the enterprise. This requires the formation of theoretical and practical approaches to managing social investment process.

\section{REFERENCE}

[1] M. Blowfield, and A. Murray, Corporate Responsibility. Cary, NC, USA: Oxford University Press, 2011.

[2] A. Zinchenko, and M. Saprykina, CSR Development in Ukraine: 2010-2018, Kyiv, Ukraine: Printing House "Yuston", 2017. [in Ukrainian]

[3] V Vorobey, I. Zhuravskaya, and Y. Shcherbinina Non-Financial Reporting: Instrument of Socially Responsible Business. Kyiv, Ukraine: UN Delegation to Ukraine, 2010. [in Ukrainian]

[4] A. Dahlsrud, "How Corporate Social Responsibility is Defined: an Analysis of 37 Definitions", Corporate Social Responsibility and Environmental Management, no 15, pp. 1-13, 2008. [Online]. Available: http://dx.doi.org/10.1002/csr.132. Accessed on: August 16, 2019

[5] M. Jankalová, "Approaches to the Evaluation of Corporate Social Responsibility", Procedia Economics and Finance, no 39, pp. 580587, 2016.

[6] M. Jankalová, and R. Jankal, "The assessment of corporate social responsibility: approaches analysis", Entrepreneurship and Sustainability Issues, vol. 4, no 4, pp. 441-459, 2017. [Online]. Available: https://doi.org/10.9770/jesi.2017.4.4(4). Accessed on: August 11, 2019.

[7] Methodology for rating the openness and systematic nature of companies in the field of CSR. [Online]. Available: http://kontrakty.ua/doc/methods_CSR_2013.pdf. Accessed on: August 16, 2019. [in Russian]

[8] B. Sheehy, "Defining CSR: problems and solutions", J. Bus. Ethics, no 131 , pp. 625-648, 2015.

[9] A.B. Carroll, "The pyramid of corporate social responsibility: Toward the moral management of organizational stakeholders", Business Horizons, vol. 34, no 4, pp. 39-48, 1991.

[10] A. García-Chiang, "Corporate social responsibility in the Mexican oil industry: Social impact assessment as a tool for local development", International Journal of Corporate Social Responsibility, vol. 3, no 15, 2018. [Online]. Available: https://doi.org/10.1186/s40991-0180038-z. Accessed on: August 23, 2019. 